\title{
Etiology of Parkinson's Disease
}

\author{
Zhigao Huang, Raúl de la Fuente-Fernández, A. Jon Stoessl
}

\begin{abstract}
There is growing recognition that Parkinson's disease (PD) is likely to arise from the combined effects of genetic predisposition as well as largely unidentified environmental factors. The relative contribution of each varies from one individual to another. Even in situations where more than one family member is affected, the predominant influence may be environmental. Although responsible for only a small minority of cases of PD, recently identified genetic mutations have provided tremendous insights into the basis for neurodegeneration and have led to growing recognition of the importance of abnormal protein handling in Parkinson's as well as other neurodegenerative disorders. Abnormal protein handling may increase susceptibility to oxidative stress; conversely, numerous other factors, including oxidative stress and impaired mitochondrial function can lead to impaired protein degradation. A limited number of environmental factors are known to be toxic to the substantia nigra; in contrast, some factors such as caffeine intake and cigarette smoking may protect against the development of PD, although the mechanisms are not established. We review the various genetic and environmental factors thought to be involved in PD, as well as the mechanisms that contribute to selective nigral cell death.
\end{abstract}

RÉSUMÉ: Étiologie de la maladie de Parkinson. L'opinion qui prévaut actuellement est que la maladie de Parkinson résulte de l'interaction entre une prédisposition génétique et des facteurs environnementaux qui demeurent en grande partie inconnus. La contribution relative de chacun varie d'un individu à l'autre. Même dans les familles où plus d'un membre est atteint, l'influence prédominante peut être environnementale. Bien qu'elles soient en cause dans seulement une minorité de cas de la maladie, des mutations génétiques identifiées récemment ont fourni des indices précieux sur l'étiologie de la dégénérescence neuronale et ont permis de reconnaitre l'importance d'un métabolisme protéique anormal dans la maladie de Parkinson ainsi que dans d'autres maladies neurodégénératrices. Un métabolisme protéique anormal peut augmenter la susceptibilité au stress oxydatif; à l'inverse, plusieurs autres facteurs, dont le stress oxydatif et une fonction mitochondriale altérée, peuvent induire une altération de la dégradation protéique. On connaît l'effet toxique d'un certain nombre de facteurs environnementaux sur la substance noire; par contre, certains facteurs tels la consommation de caféine et le tabagisme pourraient protéger de la maladie de Parkinson, bien que les mécanismes n'en soient pas établis. Nous revoyons les différents facteurs génétiques et environnementaux qu'on pense impliqués dans la maladie de Parkinson ainsi que les mécanismes qui contribuent à la mort sélective de cellules de la substance noire.

Can. J. Neurol. Sci. 2003; 30: Suppl. 1 - S10-S18

The prevalence of Parkinson's disease (PD) is 200-300 cases per 100,000 persons, with an overall estimated annual incidence of 12 cases per $100,000 .^{1}$ The prevalence is heavily agedependent, estimated at $1 \%$ in subjects over the age of 65 , and increasing to $4.3 \%$ in those over 85 years of age. ${ }^{2}$ In addition, there seems to be a gender effect; men have a somewhat higher risk of PD than women. ${ }^{3}$

Despite intense research efforts over many years, the cause(s) of PD still await elucidation. Over the past two decades, scientific opinion has varied between two extreme poles: from a position in which only environmental factors were deemed to be relevant, to a position where genetic factors were considered to be dominant. The importance of heredity in the etiology of PD has been strengthened by the discovery of some kindreds with rare genetic forms of PD. ${ }^{4,5}$ Environmental risk factors, including exposure to pesticides and metals, well water drinking, rural living and farming, have been investigated in many recent case-control and epidemiological studies. ${ }^{6-9}$ The common view today is that PD results from the combined effects of genetic susceptibility, environmental exposure and complex geneticenvironmental interactions. Aging is also a likely contributory factor. ${ }^{10}$ Several mechanisms have been proposed to explain cell death in PD, including oxidative stress, mitochondrial dysfunction, apoptosis, excitotoxicity and inflammatory responses.

From the Pacific Parkinson's Research Centre, University of British Columbia, Vancouver, BC, Canada

Reprint requests to: A. Jon Stoessl, Pacific Parkinson's Research Centre, University of British Columbia, Vancouver Hospital \& Health Sciences Centre, Purdy Pavilion, 2221 Wesbrook Mall, Vancouver, BC, Canada V6T2B5. 


\section{Parkinson's disease in different populations}

Although PD has a worldwide distribution, incidence rates may vary among populations. The results are, however, somewhat contradictory. Thus, while the prevalence of PD has been reported to be relatively low in South African and Nigerian blacks, blacks living in Mississippi are affected to a comparable degree as the white population. ${ }^{11}$ Also, an autopsy study found that black Africans have an equivalent prevalence of incidental Lewy body disease as compared with white populations. ${ }^{12}$ Similarly, while lower prevalence rates have also been reported in some Oriental populations, ${ }^{13,14}$ the prevalence of PD in Taiwan is much higher and closer to that in Western countries. ${ }^{15}$ Even if population differences in PD incidence do exist, the question still remains as to the relative contribution of genetic or environmental variations to such differences.

There is also evidence that PD patients are more likely to have a close relative with PD compared to controls. ${ }^{3,16}$ This observation, however, does not necessarily imply genetic causation. Shared environmental exposure could also explain some of the patterns of familial aggregation observed in PD. ${ }^{17}$ For example, disease onset among affected family members seems to cluster around the same calendar year, which supports a shared environmental exposure. ${ }^{18}$

\section{GENETIC FACTORS AND ABNORMAL PROTEIN PROCESSING}

There is increasing interest in the heritability of PD. This heightened interest was greatly promoted by the clinical observation of familial aggregation of PD cases ${ }^{3,19}$ and by the discovery of families with genetic forms of parkinsonism. , $^{4,20,21}$ Nevertheless, we have already noted that familial aggregation does not necessarily imply genetic causation ${ }^{17,18}$ and that most PD cases test negative for known mutations. In fact, a recent large twin study comparing clinical concordance rates between monozygotic and dizygotic twins detected increased concordance only in monozygotic twins who developed PD symptoms before the age of 50 years; no increased concordance was found in those who manifested disease at a later age. ${ }^{22}$ Although a small twin study using both clinical assessment and $\left[{ }^{18} \mathrm{~F}\right]$ fluoro-dopa positron emission tomography did report increased concordance among identical twins, ${ }^{23}$ this important observation needs to be confirmed in further studies. The effect of maternal factors on their children's risk of PD may mask the distinction between environmental and genetic causation. ${ }^{24} \mathrm{~A}$ recent epidemiological, statistical and mathematical study on PD patients and their parents showed that the child's risk of PD was related to the child's age at the time the parent developed PD rather than the parental age at onset of PD. ${ }^{25}$ Thus, the younger the child at the time the parent developed PD, the higher the risk for the child. This relationship was especially apparent when the affected parent was the mother. The degree to which parents and children share their environment usually decreases with age. Furthermore, for inherited illnesses, the risk for the child is usually related to parental age at onset. Taken together, the observations support the notion that most PD cases, including most familial cases (at least those families in which only two members are affected), are due to shared environmental exposure.

Although genetic mutations have only been associated with rare forms of parkinsonism, the discovery of these genes has provided a tremendous insight into the pathogenesis of PD. The role of abnormal protein processing in particular has now been recognized as a major mechanism of cell death not only in genetic forms of parkinsonism ${ }^{26,27}$ but also in sporadic $\mathrm{PD}^{28}$ and in other neurodegenerative disorders. ${ }^{28,29}$

Mutations in three identified genes have been associated with parkinsonism: $\alpha$-synuclein, on locus $4 \mathrm{q} 21-23,{ }^{4,21}$ parkin on locus 6q25.2-27 and ubiquitin C-terminal hydrolase L1 (UCH-L1), on locus $4 \mathrm{p} 14 .{ }^{30}$ Moreover, five additional gene loci with linkage to inherited parkinsonism have recently been identified: $2 \mathrm{p} 13,{ }^{20}$ $4 \mathrm{p} 14-16,{ }^{31} 1 \mathrm{p} 35-35,{ }^{32} 1 \mathrm{p} 36^{33}$ and $12 \mathrm{p} 11.2-\mathrm{q} 13.1^{34}$ (Table), and there is evidence for additional loci. ${ }^{3,35}$ Whereas only two disease causing mutations, A53T and A30P, of $\alpha$-synuclein have been identified, ${ }^{4,21}$ multiple mutations in the parkin gene have already been described. ${ }^{36,37}$ The phenotype associated with $\alpha$-synuclein and parkin mutations is variable. While parkinsonism arising from mutation in the $\alpha$-synuclein gene is usually characterized by an early age at onset compared to sporadic PD, parkinassociated parkinsonism has been reported with onset in the 7 th decade (in addition to the originally described juvenile onset). To date, only one $U C H-L 1$ mutation has been described ${ }^{30}$ and the relationship to disease has been controversial. ${ }^{38,39}$

All proteins currently associated with monogenic forms of parkinsonism appear to be involved in the ubiquitin-mediated

Table: Genes responsible for parkinsonism

\begin{tabular}{|c|c|c|c|c|}
\hline Gene & Locus & Inheritance & Phenotype & Reference \\
\hline$\alpha$-synuclein & $4 q 21-23$ & Autosomal dominant & Early onset PD & $\begin{array}{l}\text { Polymeropoulos et al., } 1997^{4} \\
\text { Kruger et al., } 1998^{21}\end{array}$ \\
\hline parkin & $6 q 25.2-27$ & Autosomal recessive & Juvenile onset PD & Kitada et al., $1998^{5}$ \\
\hline UCH-L1 & $4 \mathrm{p} 14$ & Autosomal dominant & Typical PD & Leroy et al., $1998^{30}$ \\
\hline PARK3 & $2 \mathrm{p} 13$ & Autosomal dominant & Typical PD & Gasser et al., $1998^{20}$ \\
\hline PARK4 & $4 p 14-16$ & Autosomal dominant & $\mathrm{PD} /$ Essential tremor & Farrer et al., $1999^{31}$ \\
\hline PARK6 & $1 \mathrm{p} 35-35$ & Autosomal recessive & Early onset PD & Valente et la., $2001^{32}$ \\
\hline PARK7 & $1 \mathrm{p} 36$ & Autosomal recessive & Early onset PD & van Duijn et al., $2001^{33}$ \\
\hline PARK8 & 12p11.2-q13.1 & Autosomal dominant & Typical PD & Funayama et al., $2002^{34}$ \\
\hline
\end{tabular}


pathway of protein degradation. Proteins that are degraded through this system are tagged with polyubiquitin chains through a series of enzymatic reactions and then degraded by the proteasome, a multicatalytic complex. ${ }^{40}$ Some ubiquitinated proteins may also be degraded by the lysosomal system. ${ }^{41} \alpha$ Synuclein is a protein localized within presynaptic terminals in the central nervous system $(\mathrm{CNS})^{42}$ and, together with ubiquitin, is a major component of the filaments associated with Lewy bodies. ${ }^{43}$ Parkinsonism associated with mutations of $\alpha$-synuclein resembles clinically sporadic PD, and is characterized by the presence of Lewy bodies in surviving cells of the substantia nigra. Expression of mutant $\mathrm{A} 53 \mathrm{~T}^{44}$ or $\mathrm{A} 30 \mathrm{P}^{21} \alpha$-synuclein leads to the formation of small ubiquitinated aggregates, and to autophagic cellular degeneration. These effects are accompanied by, and may be consequences of, defects in the lysosomal and proteasomal degradation systems. ${ }^{40,45}$ Transgenic expression of human $\alpha$-synuclein results in degeneration of dopaminergic terminals in the mouse $\mathrm{e}^{46}$ and loss of dopaminergic neurons in Drosophila. $^{47}$ In the latter model, degeneration is even greater when mutant human $\alpha$-synuclein (either A30P or A53T) is expressed, and there is formation of abnormal protein inclusions reminiscent of Lewy bodies. ${ }^{47}$ Aberrant $\alpha$-synuclein appears to increase cell vulnerability to oxidative stress ${ }^{48}$ and conversely, oxidative stress may result in increased $\alpha$-synuclein aggregation. ${ }^{49} \alpha$-Synuclein accumulation appears to result in dopamine-dependent apoptosis ${ }^{49 a}$ this may be one explanation for the selectivity of neuronal loss seen in parkinsonism.

A juvenile autosomal recessive form of parkinsonism was initially described in Japan and was found to be characterized by selective loss of nigral dopamine neurons, without Lewy bodies. ${ }^{50}$ This disorder, which is caused by mutations of the parkin gene, ${ }^{5}$ has now been shown to have a worldwide distribution, particularly among patients younger than 50 years of age. ${ }^{36,51}$ Parkin (the gene product) functions as an E3 ubiquitin-protein ligase, responsible for the attachment of ubiquitin to substrates such as synaptic vesicle-associated protein, PNUTL1 (drosophila peanut-like gene 1 protein)/ CDCrel-1,52 parkin-associated endothelin receptor-like receptor (Pael receptor), ${ }^{53}$ and a glycosylated form of $\alpha$-synuclein ${ }^{54}$ It has been suggested that mutations in the parkin gene could result in abnormal accumulation of its substrate proteins, which could potentially lead to inhibition of transmitter release and/or insoluble Pael-R mediated cell death. ${ }^{53}$

A mutation in the gene encoding for $U C H-L 1$ has been associated with parkinsonism in one family. ${ }^{30} \mathrm{UCH}-\mathrm{Ll}$ is an enzyme that hydrolyzes small C-terminal adducts of ubiquitin to generate ubiquitin monomers, which can then be recycled and used to clear other proteins. The mutant form of $U C H-L 1$ has diminished enzymatic activity resulting in impaired protein clearance through the ubiquitin-proteasome pathway. ${ }^{41}$

\section{ENVIRONMENTAL FACTORS}

Several epidemiological studies have given support to the environmental hypothesis of PD. ${ }^{3,55}$ Most studies agree on the role played by pesticide exposure and smoking on the risk of PD. ${ }^{3,6}$ While the exposure to pesticides may be associated with an increased risk of PD, smoking seems to play a protective role. Other factors often imputed to increase the risk of PD (e.g., head trauma) have not been supported by consistent evidence. ${ }^{56}$ In addition, many of these factors may be associated with one another, which poses difficulties in teasing apart their individual contribution, if any. For example, rural living, well water drinking, and farming activity may be compound risk factors. ${ }^{6}$ Young-onset parkinsonism in particular has been associated with exposure to well water. ${ }^{57}$ While no toxic constituents have been identified, well water drinking may simply be a marker for rural environment, which might, in turn, point to pesticide exposure. Dietary factors have also been purported to have an effect on the risk of PD. ${ }^{3}$ Thus, for example, consumption of products containing niacin may reduce the risk $;^{58}$ diets heavily dependent on animal fat, on the other hand, may increase the risk of PD. ${ }^{59,60}$ No evidence has yet been provided to support a role for antioxidants (e.g., vitamin E) as potential neuroprotective agents. $^{3}$

As noted above, a key factor in the etiology of PD may be pesticide exposure, ${ }^{3,6,8,9,61}$ this association has recently been confirmed in the meta-analysis by Priyadarshi and colleagues. ${ }^{62}$ There is also some evidence that exposure to pesticides may increase mortality in PD patients. ${ }^{63}$ It should be noted that most studies grouped several agents, including pesticides, herbicides, and insecticides, as "pesticides". Hence, we do not know the risk associated with each specific substance. Interestingly, the potential relationship between pesticides and PD has received experimental support from the recent demonstration of selective nigral dopaminergic cell degeneration in rats exposed to chronic low-dose rotenone. ${ }^{64}$ The rotenone model, if confirmed, may help identify specific factors involved in the etiology of PD. Rotenone-induced dopaminergic neuronal degeneration is thought to result from selective dysfunction of mitochondrial Complex I, as is the case for the other selective dopaminergic neurotoxin 1-methyl-4-phenyl-1,2,3,6-tetrahydropyridine (MPTP) (see discussion below). MPTP results in parkinsonism in both humans ${ }^{65}$ and experimental animals. ${ }^{66}$ Associations between PD and exposure to plastic or epoxy resin and metals such as manganese $\mathrm{e}^{7,67}$ have also been reported, but the results are less consistent. $^{68,69}$ It has also been suggested that exposure to industrial toxins may explain the higher risk in urban compared to rural environments found in China. ${ }^{70}$

In contrast to pesticide exposure, numerous investigators have suggested an inverse relationship between smoking and the risk of PD, ${ }^{3,71-74}$ although not all studies have found such an association. ${ }^{70,75,76}$ Whereas a case-control study confirmed a lower prevalence of current smoking in parkinsonian patients, but no difference in prior exposure (suggesting that there is no protective effect, but rather that PD itself leads to reduced smoking), ${ }^{75}$ a recent study demonstrated that the risk of PD is inversely correlated with the dose of cigarette smoking in twin pairs. ${ }^{77}$ This effect is most pronounced in monozygotic twins. Another prospective study of more than 8,000 men enrolled in the Honolulu Heart Program did indeed support a reduced risk of PD in smokers or ex-smokers, with an apparent dose-response effect. ${ }^{78}$ Similarly, this inverse relationship was found to be more striking among current smokers than among ex-smokers. ${ }^{71}$ If the relationship is indeed a real one, there still exists the question of whether it reflects a 'rigid' premorbid personality trait, as has been repeatedly described in $\mathrm{PD},{ }^{56}$ or a lower propensity to nicotine addiction (perhaps in relation to dysfunctional reward 
mechanisms), rather than a 'protective' effect of smoking. Nevertheless, there is some evidence to suggest that nicotine may indeed play a protective role in $\mathrm{PD},{ }^{79}$ possibly acting on toxin-neutralizing enzymatic pathways. ${ }^{80}$ Cerebral MAO-B activity was reported to be significantly lower in heavy cigarette smokers than in nonsmokers. ${ }^{81}$ A more recent study demonstrated that nicotine was capable of inducing neurotrophic factors, such as basic fibroblast growth factor, in the striatum. ${ }^{82}$ It has been suggested that caffeine intake may also decrease the risk of PD, independently of the effect of smoking. ${ }^{83}$ This may correspond to recent evidence for a neuroprotective effect of adenosine receptor blockade in experimental models of parkinsonism. ${ }^{84,85}$

There is some evidence to suggest that PD may be more prevalent in certain occupations. A recent study suggested a higher risk of PD among physicians, teachers, miners and loggers. ${ }^{86}$ One could argue that miners and loggers may be preferentially exposed to some of the neurotoxins mentioned earlier. This explanation, however, would not apply to physicians and teachers. Given the heavy exposure of physicians and teachers to the public at large and the shared environment due to frequently cramped living arrangements for the latter two (often staying in crowded camps while working), the authors of the study proposed that PD could be due to droplet-spread infections (especially viral infections). Indeed, although viruses have been neglected as potential agents, several threads of evidence indicate that they deserve attention.

It is now generally believed that the pandemic of encephalitis lethargica, which occurred in the early 20th century, was probably related to influenza infection. ${ }^{87,88}$ Like PD, postencephalitic parkinsonism is also associated with late progression. ${ }^{89}$ In addition, clinically typical parkinsonism with image evidence of damage confined to the substantia nigra has been reported in patients with sporadic encephalitis ${ }^{90}$ and there is experimental evidence that the substantia nigra is particularly vulnerable to virulent influenza A virus. ${ }^{91}$ Naturally, other viruses could also be involved in the etiology of PD. ${ }^{92}$ Most importantly, a recent mathematical model based on the age at onset of PD symptoms predicts that PD is caused by exposure to randomly distributed discrete events. ${ }^{25}$ Infections in general (and viral infections in particular) may well be such discrete events.

\section{MeChaNiSMS OF CELL DEATH}

We have already seen that abnormal protein processing is likely to play a pivotal role in cell death in PD and, perhaps, in other neurodegenerative disorders as well. We will review now other factors - namely, oxidative stress, mitochondrial dysfunction, apoptosis, excitotoxicity, and inflammation - that may also be involved. None of these factors should, however, be seen as mutually exclusive. Abnormal protein processing, for example, may increase the susceptibility to oxidative stress (and vice versa). Impaired mitochondrial function may promote both excitotoxicity and free radical damage. Naturally, environmental toxins could act at any of these stages, with the common end result of selective nigral death (Figure).

\section{Oxidative stress}

Oxidative stress is thought to play a pathogenic role in PD. This has been evidenced by increased lipid peroxidation, ${ }^{40}$ reduced glutathione levels ${ }^{93,94}$ a high concentration of iron and reactive oxygen free radical generation via autocatalytic mechanisms within neuromelanin-containing catecholaminergic neurons in the substantia nigra. ${ }^{40,95}$ In addition, the observation that exogenous administration of cysteine, $\mathrm{N}$-acetyl cysteine or glutathione decreased the neurotoxic effects of 6-hydroxydopamine (6-OHDA) in vitro and in vivo reinforces this hypothesis. ${ }^{96}$ It is recognized that dopamine itself undergoes both enzymatic and nonenzymatic reactions that result in the formation of toxic radicals. ${ }^{97}$

One such toxic radical is the superoxide anion which, under normal circumstances, is cleared by superoxide dismutase (SOD1), resulting in the formation of hydrogen peroxide. ${ }^{98,99}$ Hydrogen peroxide is, in turn, usually cleared by reduced glutathione (via glutathione peroxidase) or catalase but there is a deficiency of reduced gluthatione in the substantia nigra of parkinsonian subjects. ${ }^{100}$ Gluthatione deficiency appears to result at least in part from increased activity of the degradative enzyme $\gamma$-glutamyltranspeptidase. Thus, in PD, there may be an excess of hydrogen peroxide, which is now free to undergo nonenzymatic (Fenton) reactions with iron, thereby resulting in the formation of highly toxic hydroxyl radicals. ${ }^{97}$ While there is evidence for increased lipid peroxidase and abnormally oxidized DNA ${ }^{98,99}$ in PD, these findings are not restricted to the substantia nigra and it is not clear to what extent they may reflect the effects of treatment. One obvious concern which arose from the free radical hypothesis was the possibility that levodopa itself could be toxic to substantia nigra neurons; there is, however, no in vivo evidence that this is the case. ${ }^{101}$ While high concentrations of levodopa in artificial conditions do indeed result in oxidative cell death, ${ }^{102}$, levodopa could even be neuroprotective to neurons of the substantia nigra in rodent models ${ }^{103}$ and in humans. ${ }^{104}$

Selegiline is a potent and selective monoamine oxidase B (MAO-B) inhibitor. This led to speculation that selegiline could be neuroprotective by diminishing oxidative stress. Unfortunately there is no convincing clinical evidence for a neuroprotective effect of selegiline. ${ }^{105,106}$ More recently, a new MAO-B inhibitor (rasagiline) has shown some experimental promise $^{107}$ and is currently under investigation. ${ }^{108}$ However, in both cases, any protective effects may be independent of MAO$\mathrm{B}$ inhibition. ${ }^{109,110}$ The mechanism of action has been related to either altering protein synthesis ${ }^{109}$ or stablizing mitochondrial membrane potential, ${ }^{111}$ thus protecting neuronal cells against apoptotic injury.

\section{Mitochondrial dysfunction}

Mitochondrial DNAdeletions or point mutations that cause a reduced capacity for oxidative phosphorylation (OXPHOS) result in a number of diseases and pathologies. ${ }^{112,113}$ Mitochondria play a critical role in the health and survival of cells by providing the energy that fuels the maintenance, repair, and turnover of cellular components. Deterioration of mitochondrial function is therefore thought to play a major role in aging and neurological diseases as a result of the buildup of damage caused by reactive oxygen free radicals produced by the mitochondrion itself during oxidative phosphorylation. ${ }^{114,115}$ Reactive oxygen free radical production is a function both of the inefficiency of transfer of electrons through the respiratory chain and the level of antioxidant defenses in the cell. 


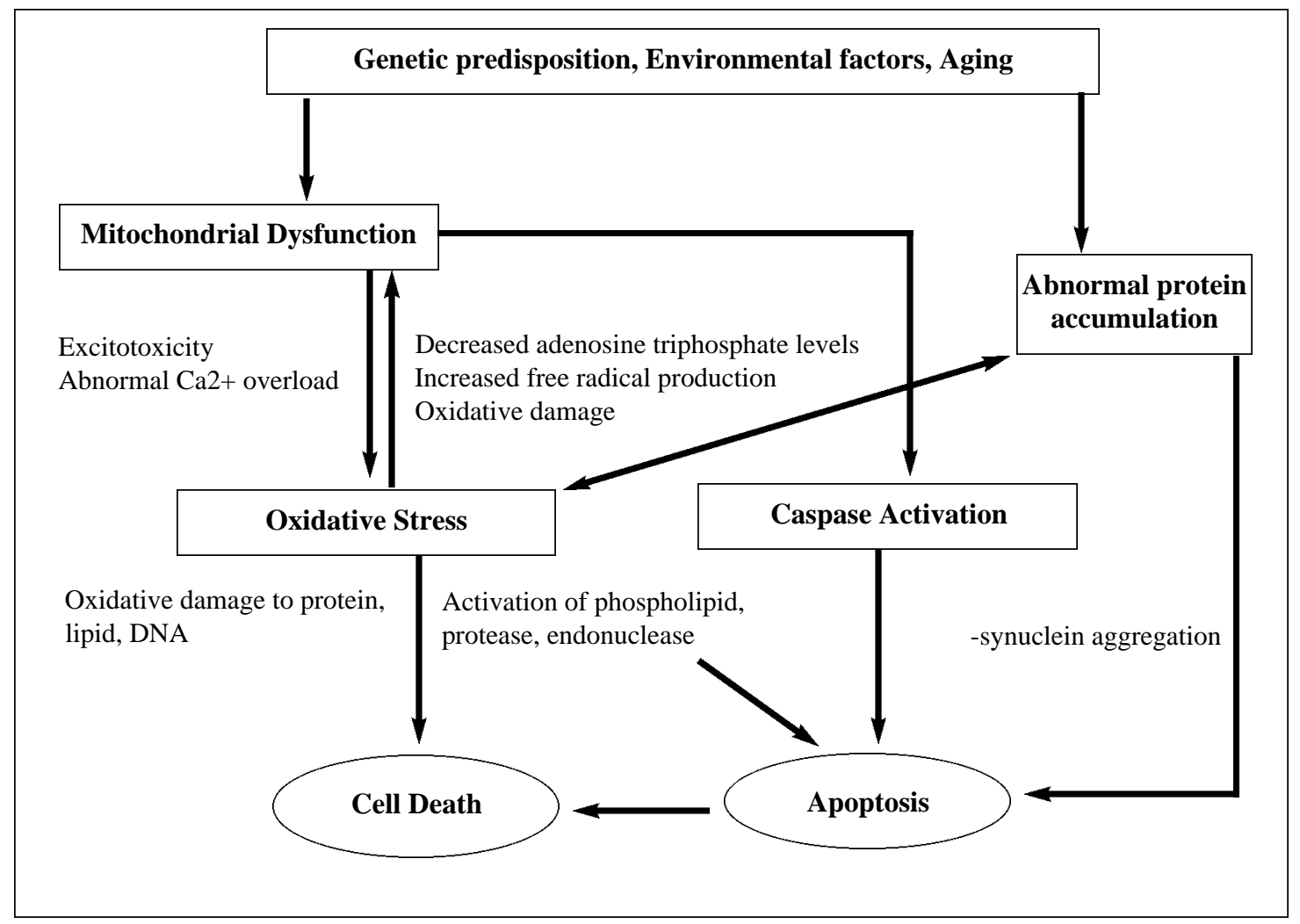

Figure: Possible mechanisms leading to the neuronal cell death in PD. Inflammatory responses may occur at different levels of the cascade leading to cell death.

The discovery that MPTP exposure produces CNS pathology very similar to that observed in PD strengthened the hypothesis that PD could be caused by exogenous or endogenous neurotoxins, and provided a heuristic model for investigating the pathological process of PD in animals. The first stage in the mechanism of action of MPTP is its deamination by MAO-B in glial cells, which results in the formation of the 1-methyl-4phenylpyridinium ion (MPP+). MPP+ is then selectively accumulated in dopamine nerve terminals by the plasma membrane dopamine transporter. Once inside the dopamine nerve terminals, MPP+ acts in a manner similar to 6-OHDA by generating hydrogen peroxide and other free radicals that interfere with mitochondrial respiration. ${ }^{116} \mathrm{MPP}+$ is concentrated in mitochondria, where it impairs mitochondrial respiration by inhibiting complex I of the electron transfer complex and consequently causing the death of neurons. It has also been suggested that the neuromelanin present in dopaminergic neurons may act as a storage site for MPP+ or other neurotoxins. Hence, MPTP-related dopaminergic cell death is caused by oxidative stress followed by lipid peroxidation brought about by inhibition of mitochondrial enzymes participating in the synthesis of adenosine triphosphate. In experimental models, selegiline protects substantia nigra neurons by blocking the conversion of MPTP to MPP+. ${ }^{117}$

There is fairly consistent evidence for impairment of mitochondrial complex I function in PD. Complex I deficiency was first identified in the substantia nigra of postmortem PD brain. ${ }^{118-120}$ The complex I defect appears to be specific and restricted to the substantia nigra, i.e., other brain areas, including striatum, cortex, cerebellum, globus pallidus and substantia innominata were reported to have normal OXPHOS activity. ${ }^{118,119}$ There are also reports of reduced complex I activity in muscle ${ }^{121}$ and platelets ${ }^{122}$ in PD patients, suggesting systemic involvement. The importance of impaired complex I function in the pathogenesis of PD received further support from the demonstration of selective nigral death following chronic exposure to rotenone, a well-known inhibitor of complex I. ${ }^{64}$ Unlike MPP+, rotenone is not dependent upon selective uptake via the membrane dopamine transporter. However, other reports have suggested additional defects in complexes II and III, as well as abnormal immunoreactivity for $\alpha$-ketoglutarate, an enzyme of the citric acid cycle. ${ }^{123}$ In multiple system atrophy, a disorder with degeneration of neurons in substantia nigra, no OXPHOS defect was found ${ }^{124}$ and there was no complex I abnormality in Lewy body rich cingulate cortex of diffuse Lewy body brains. ${ }^{118}$ This suggests that the complex I defect is specific to PD and selective for the substantia nigra but not related to the formation of Lewy bodies.

\section{Apoptosis}

A number of reports have demonstrated apoptotic cell death in the substantia nigra of parkinsonian patients, ${ }^{125-127}$ but this is still somewhat controversial and some studies have reported little or no evidence of apoptotic cell death in PD tissue. ${ }^{128-130}$ 
Furthermore, the presence of apoptosis does not necessarily provide significant insight into the etiopathogenesis of selective cell death in PD, as oxidative stress, mitochondrial dysfunction and excitotoxicity (see below) can all result in apoptotic death rather than necrosis, depending, perhaps, on a dose effect.

A number of pro- and anti-apoptotic genes have been reported to be associated with PD. Activated caspase 3, considered the major downstream caspase involved in the execution phase of neuronal cell death, has been detected in the substantia nigra of PD patients. ${ }^{131}$. Nevertheless, it has been suggested that this caspase activation may occur in reactive astrocytes and microglial cells rather than in neurons themselves. ${ }^{132}$ Recent studies suggest that activated forms of both caspase 8 and caspase 9, upstream caspases that are known to cleave and activate caspase 3 , are present in dopaminergic neurons of the substantia nigra in MPTP-treated mice. ${ }^{133}$ Caspase-mediated parkin cleavage that compromises parkin function was also recently demonstrated in cell lines. ${ }^{134}$ Upregulation of the antiapoptotic gene $b c l-2^{135}$ may, on the other hand, reflect an incomplete compensatory response; it is also possible that neurons expressing higher levels of $b c l-2$ are those more likely to survive. A selective elevation of calpain activity in dopaminergic neurons of the substantia nigra further supports the notion of active apoptosis. ${ }^{136}$ There is a single report of increased translocation of NF- $\mathrm{KB}$ in the substantia nigra of parkinsonian subjects; ${ }^{137}$ this study has not yet been replicated and it is not clear whether such increased translocation represents active apoptosis or a compensatory response.

\section{Excitotoxicity}

Although there is no direct evidence for increased levels of excitatory amino acids prior to the onset of symptomatic PD, it has been suggested that mitochondrial dysfunction might promote toxicity resulting from normal levels of excitatory amino acid transmission. ${ }^{138}$ Interestingly, treatment with amantadine, a weak N-methyl-D-aspartate blocker, is associated with prolonged survival in PD. ${ }^{139}$ However, there is no direct evidence for neuroprotective effects of excitatory amino acid antagonists. Clinical trials of the sodium-dependent glutamate release blocker riluzole were recently terminated due to lack of clear benefit.

\section{Inflammatory response}

Activated microglia have been demonstrated in the substantia nigra in PD and other degenerative disorders. ${ }^{140}$ Inflammatory and glial responses have also been observed in the substantia nigra of patients exposed to MPTP ${ }^{141}$ and in MPTP-treated primates. ${ }^{66}$ In addition, a significant inflammatory response to progressive dopaminergic degeneration was recently also demonstrated in the nigrostriatal system of animals after 6OHDAadministration. ${ }^{142}$

It is not clear, however, whether inflammation plays a primary role or whether it represents a secondary phenomenon. Although there have been reports of disease-specific antineuronal antibodies in the cerebrospinal fluid and there may be complement-dependent dopaminergic toxicity in PD serum, ${ }^{143}$ there is no direct evidence to suggest a primary immunological abnormality in PD. Interestingly, treatment with aspirin was found to attenuate MPTPtoxicity in mice. ${ }^{144}$

\section{ConcLusion}

The etiology of PD remains a mystery. Specific environmental and genetic factors, as well as complex geneticenvironmental interactions are likely to be involved. Current evidence suggests that environmental exposure plays a major role in the majority of PD cases. It should be noted, however, that no specific agent has yet been identified. Experiments based on recently discovered mutations in $\alpha$-synuclein and parkin genes have provided evidence to suggest that abnormal protein processing leading to aberrant protein accumulation is a major pathogenetic mechanism in PD. Contributory mechanisms of cell death in PD include, excessive generation of free radicals, impaired function of mitochondrial complex I and inflammatory responses; abnormal regulation of 'pro- or anti-apoptotic'factors and excitotoxicity may also be involved. Improved understanding of these issues will allow the development of more rational treatment strategies for PD and, perhaps, for other neurodegenerative disorders as well.

\section{REFERENCES}

1. Tanner CM, Hubble JP, Chan P. Epidemiology and genetics of Parkinson's disease. In: Watts RL, Koller WC, (Eds). Movement Disorders. New York: McGraw-Hill, 1997: 137-152.

2. de Rijk MC, Breteler MM, Graveland GA, et al. Prevalence of Parkinson's disease in the elderly: the Rotterdam Study. Neurology 1995; 45(12):2143-2146.

3. Goldman SM, Tanner CM. Etiology of Parkinson's disease. In: Jankovic J, Tolosa E, (Eds). Parkinson's Disease and Movement Disorders. Baltimore, Maryland: Williams and Wilkins, 1998: 133-158.

4. Polymeropoulos MH, Lavedan C, Leroy E, et al. Mutation in the alpha-synuclein gene identified in families with Parkinson's disease. Science 1997; 276(5321): 2045-2047.

5. Kitada T, Asakawa S, Hattori N, et al. Mutations in the parkin gene cause autosomal recessive juvenile parkinsonism. Nature 1998; 392(6676):605-608

6. Lai BCL, Marion SA, Teschke K, Tsui JKC. Occupational and environmental risk factors for Parkinson's disease. Parkinsonism and Related Disorders 2002; 8:297-309.

7. Gorell JM, Johnson CC, Rybicki BA, et al. Occupational exposures to metals as risk factors for Parkinson's disease. Neurology 1997; 48(3):650-658.

8. Gorell JM, Johnson CC, Rybicki BA, Peterson EL, Richardson RJ. The risk of Parkinson's disease with exposure to pesticides, farming, well water, and rural living. Neurology 1998; 50(5):1346-1350.

9. Zorzon M, Capus L, Pellegrino A, Cazzato G, Zivadinov R. Familial and environmental risk factors in Parkinson's disease: a case-control study in north-east Italy. Acta Neurol Scand 2002; 105(2):77-82.

10. Calne DB, Langston JW. Aetiology of Parkinson's disease. Lancet 1983; 2(8365-66):1457-1459.

11. Schoenberg BS, Anderson DW, Haerer AF. Prevalence of Parkinson's disease in the biracial population of Copiah County, Mississippi. Neurology 1985; 35(6):841-845.

12. Jendroska K, Olasode BJ, Daniel SE, et al. Incidental Lewy body disease in black Africans. Lancet 1994; 344(8926):882-883.

13. Wang SJ, Fuh JL, Teng EL, et al. A door-to-door survey of Parkinson's disease in a Chinese population in Kinmen. Arch Neurol 1996; 53(1):66-71.

14. Zhang ZX, Roman GC. Worldwide occurrence of Parkinson's disease: an updated review. Neuroepidemiology 1993; 12(4):195-208.

15. Chen RC, Chang SF, Su CL, et al. Prevalence, incidence, and mortality of PD: a door-to-door survey in Ilan county, Taiwan. Neurology 2001; 57(9):1679-1686. 
16. Payami H, Zareparsi S, James D, Nutt J. Familial aggregation of Parkinson's disease: a comparative study of early- onset and late-onset disease. Arch Neurol 2002; 59(5):848-850.

17. de la Fuente-Fernandez R, Calne DB. Familial aggregation of Parkinson's disease. N Engl J Med 2001; 344(15):1168.

18. Calne S, Schoenberg B, Martin W, et al. Familial Parkinson's disease: possible role of environmental factors. Can J Neurol Sci 1987; 14(3):303-305.

19. Sveinbjornsdottir S, Hicks AA, Jonsson T, et al. Familial aggregation of Parkinson's disease in Iceland. N Engl J Med 2000; 343(24): 1765-1770.

20. Gasser T, Muller-Myhsok B, Wszolek ZK, et al. A susceptibility locus for Parkinson's disease maps to chromosome 2p13. Nat Genet 1998; 18(3):262-265.

21. Kruger R, Kuhn W, Muller T, et al. Ala30Pro mutation in the gene encoding alpha-synuclein in Parkinson's disease. Nat Genet 1998; 18(2):106-108.

22. Tanner CM, Ottman R, Goldman SM, et al. Parkinson disease in twins: an etiologic study. JAMA1999; 281(4):341-346.

23. Piccini P, Burn DJ, Ceravolo R, Maraganore D, Brooks DJ. The role of inheritance in sporadic Parkinson's disease: evidence from a longitudinal study of dopaminergic function in twins. Ann Neurol 1999; 45(5):577-582.

24. de la Fuente-Fernandez R. Maternal effect on Parkinson's disease. Ann Neurol 2000; 48(5):782-787.

25. de la Fuente-Fernandez R, Calne DB. Evidence for environmental causation of Parkinson's disease. Parkinsonism and Related Disorders 2002; 8:235-241.

26. Dawson VL. Neurobiology. Of flies and mice. Science 2000; 288(5466):631-632.

27. Olanow CW, Tatton WG. Etiology and pathogenesis of Parkinson's disease. Annu Rev Neurosci 1999; 22:123-144.

28. Spillantini MG, Goedert M. Tau and Parkinson disease. JAMA 2001; 286(18):2324-2326.

29. Spillantini MG, Schmidt ML, Lee VM, et al. Alpha-synuclein in Lewy bodies. Nature 1997; 388(6645):839-840.

30. Leroy E, Boyer R, Auburger G, et al. The ubiquitin pathway in Parkinson's disease. Nature 1998; 395(6701):451-452.

31. Farrer M, Gwinn-Hardy K, Muenter M, et al. A chromosome 4p haplotype segregating with Parkinson's disease and postural tremor. Hum Mol Genet 1999; 8(1):81-85.

32. Valente EM, Bentivoglio AR, Dixon PH, et al. Localization of a novel locus for autosomal recessive early-onset parkinsonism, PARK6, on human chromosome 1p35-p36. Am J Hum Genet 2001; 68(4):895-900.

33. van Duijn CM, Dekker MC, Bonifati V, et al. Park7, a novel locus for autosomal recessive early-onset parkinsonism, on chromosome 1p36. Am J Hum Genet 2001; 69(3):629-634.

34. Funayama M, Hasegawa $\mathrm{K}$, Kowa $\mathrm{H}$, et al. A new locus for Parkinson's disease (PARK8) maps to chromosome 12p11.2q13.1. Ann Neurol 2002; 51(3):296-301.

35. Scott WK, Nance MA, Watts RL, et al. Complete genomic screen in Parkinson disease: evidence for multiple genes. JAMA2001; 286(18):2239-2244.

36. Mouradian MM. Recent advances in the genetics and pathogenesis of Parkinson disease. Neurology 2002; 58(2):179185.

37. Shastry BS. Parkinson disease: etiology, pathogenesis and future of gene therapy. Neurosci Res 2001; 41(1):5-12.

38. Gasser T. Genetics of Parkinson's disease. J Neurol 2001; 248(10):833-840.

39. Vaughan JR, Davis MB, Wood NW. Genetics of parkinsonism: a review. Ann Hum Genet 2001; 65(Pt 2):111-126.

40. Jenner P, Olanow CW. Understanding cell death in Parkinson's disease. Ann Neurol 1998; 44(3 Suppl 1):S72-S84.

41. Ciechanover A, Schwartz AL. The ubiquitin-proteasome pathway: the complexity and myriad functions of protein death. Proc Natl Acad Sci USA1998; 95(6):2727-2730.

42. Clayton DF, George JM. Synucleins in synaptic plasticity and neurodegenerative disorders. J Neurosci Res 1999; 58(1):120129.

43. Spillantini MG, Crowther RA, Jakes R, Hasegawa M, Goedert M.
Alpha-Synuclein in filamentous inclusions of Lewy bodies from Parkinson's disease and dementia with Lewy bodies. Proc Natl Acad Sci U S A 1998; 95(11):6469-6473.

44. Stefanis L, Larsen KE, Rideout HJ, Sulzer D, Greene LA. Expression of A53Tmutant but not wild-type alpha-synuclein in PC12 cells induces alterations of the ubiquitin-dependent degradation system, loss of dopamine release, and autophagic cell death. J Neurosci 2001; 21(24):9549-9560.

45. Tofaris GK, Layfield R, Spillantini MG. Alpha-synuclein metabolism and aggregation is linked to ubiquitin- independent degradation by the proteasome. FEBS Lett 2001; 509(1):22-26.

46. Masliah E, Rockenstein E, Veinbergs I, et al. Dopaminergic loss and inclusion body formation in alpha-synuclein mice: implications for neurodegenerative disorders. Science 2000; 287(5456): 1265-1269.

47. Feany MB, Bender WW. A Drosophila model of Parkinson's disease. Nature 2000; 404(6776):394-398.

48. Kanda S, Bishop JF, Eglitis MA, Yang Y, Mouradian MM. Enhanced vulnerability to oxidative stress by alpha-synuclein mutations and C-terminal truncation. Neuroscience 2000; 97(2):279-284.

49. Giasson BI, Duda JE, Murray IV, et al. Oxidative damage linked to neurodegeneration by selective alpha-synuclein nitration in synucleinopathy lesions. Science 2000; 290(5493):985-989.

49a. Xu J, Kao S-Y, Lee FJS, et al. Dopamine-dependent neurotoxicity of $\alpha$-synuclein: a mechanism for selective neurodegeneration in Parkinson disease. Nat Med 2002; 8(6): 600-606.

50. Takahashi H, Ohama E, Suzuki S, et al. Familial juvenile parkinsonism: clinical and pathologic study in a family. Neurology 1994; 44(3 Pt 1):437-441.

51. Hedrich K, Marder K, Harris J, et al. Evaluation of 50 probands with early-onset Parkinson's disease for parkin mutations. Neurology 2002; 58(8):1239-1246.

52. Zhang Y, Gao J, Chung KK, et al. Parkin functions as an E2dependent ubiquitin- protein ligase and promotes the degradation of the synaptic vesicle-associated protein, CDCrel1. Proc Natl Acad Sci U S A 2000; 97(24):13354-13359.

53. Imai $\mathrm{Y}$, Soda $\mathrm{M}$, Inoue $\mathrm{H}$, et al. An unfolded putative transmembrane polypeptide, which can lead to endoplasmic reticulum stress, is a substrate of parkin. Cell 2001; 105(7):891902.

54. Shimura H, Schlossmacher MG, Hattori N, et al. Ubiquitination of a new form of alpha-synuclein by parkin from human brain: implications for Parkinson's disease. Science 2001; 293(5528):263-269.

55. Tanner CM, Chen B, Wang WZ, et al. Environmental factors in the etiology of Parkinson's disease. Can J Neurol Sci 1987; 14(3 Suppl):419-423.

56. Golbe LI, Langston JW. The etiology of Parkinson's disease: new directions for research. In: Jankovic J, Tolosa E, (Eds). Parkinson's Disease and Movement Disorders. Baltimore, Maryland: Williams and Wilkins, 1993: 93-101.

57. Rajput AH, Uitti RJ, Stern W, et al. Geography, drinking water chemistry, pesticides and herbicides and the etiology of Parkinson's disease. Can J Neurol Sci 1987; 14(3 Suppl):414418.

58. Fall PA, Fredrikson M, Axelson O, Granerus AK. Nutritional and occupational factors influencing the risk of Parkinson's disease: a case-control study in southeastern Sweden. Mov Disord 1999; 14(1):28-37.

59. Anderson C, Checkoway H, Franklin GM, et al. Dietary factors in Parkinson's disease: the role of food groups and specific foods. Mov Disord 1999; 14(1):21-27.

60. Johnson CC, Gorell JM, Rybicki BA, Sanders K, Peterson EL. Adult nutrient intake as a risk factor for Parkinson's disease. Int J Epidemiol 1999; 28(6):1102-1109.

61. Menegon A, Board PG, Blackburn AC, Mellick GD, Le Couteur DG. Parkinson's disease, pesticides, and glutathione transferase polymorphisms. Lancet 1998; 352(9137):1344-1346.

62. Priyadarshi A, Khuder SA, Schaub EA, Shrivastava S. A metaanalysis of Parkinson's disease and exposure to pesticides. Neurotoxicology 2000; 21(4):435-440. 
63. Ritz B, Yu F. Parkinson's disease mortality and pesticide exposure in California 1984-1994. Int J Epidemiol 2000; 29(2):323-329.

64. Betarbet R, Sherer TB, MacKenzie G, et al. Chronic systemic pesticide exposure reproduces features of Parkinson's disease. Nat Neurosci 2000; 3(12):1301-1306.

65. Langston JW, Ballard P, Tetrud JW, Irwin I. Chronic parkinsonism in humans due to a product of meperidine-analog synthesis. Science 1983; 219(4587):979-980.

66. Brownell AL, Jenkins BG, Isacson O. Dopamine imaging markers and predictive mathematical models for progressive degeneration in Parkinson's disease. Biomed Pharmacother 1999; 53(3):131-140.

67. Gorell JM, Johnson CC, Rybicki BA, et al. Occupational exposure to manganese, copper, lead, iron, mercury and zinc and the risk of Parkinson's disease. Neurotoxicology 1999; 20(2-3):239247.

68. Semchuk KM, Love EJ, Lee RG. Parkinson's disease: a test of the multifactorial etiologic hypothesis. Neurology 1993; 43(6):1173-1180.

69. Vieregge P, Heinzow B, Korf G, et al. Long-term exposure to manganese in rural well water has no neurological effects. Can J Neurol Sci 1995; 22(4):286-289.

70. Wang WZ, Fang XH, Cheng XM, Jiang DH, Lin ZJ. A casecontrol study on the environmental risk factors of Parkinson's disease in Tianjin, China. Neuroepidemiology 1993; 12(4):209218.

71. Checkoway H, Powers K, Smith-Weller T, et al. Parkinson's disease risks associated with cigarette smoking, alcohol consumption, and caffeine intake. Am J Epidemiol 2002; 155(8):732-738.

72. Gorell JM, Rybicki BA, Johnson CC, Peterson EL. Smoking and Parkinson's disease: a dose-response relationship. Neurology 1999; 52(1):115-119.

73. Kuopio AM, Marttila RJ, Helenius H, Rinne UK. Environmental risk factors in Parkinson's disease. Mov Disord 1999; 14(6):928-939.

74. Preux PM, Condet A, Anglade C, et al. Parkinson's disease and environmental factors. Matched case-control study in the Limousin region, France. Neuroepidemiology 2000; 19(6):333337.

75. Mayeux R, Tang MX, Marder K, Cote LJ, Stern Y. Smoking and Parkinson's disease. Mov Disord 1994; 9(2):207-212.

76. Tzourio C, Rocca WA, Breteler MM, et al. Smoking and Parkinson's disease. An age-dependent risk effect? The EUROPARKINSON Study Group. Neurology 1997; 49(5):1267-1272.

77. Tanner CM, Goldman SM, Aston DA, et al. Smoking and Parkinson's disease in twins. Neurology 2002; 58(4):581-588.

78. Grandinetti A, Morens DM, Reed D, MacEachern D. Prospective study of cigarette smoking and the risk of developing idiopathic Parkinson's disease. Am J Epidemiol 1994; 139(12):1129-1138.

79. Quik M, Jeyarasasingam G. Nicotinic receptors and Parkinson's disease. Eur J Pharmacol 2000; 393(1-3):223-230.

80. Baron JA. Cigarette smoking and Parkinson's disease. Neurology 1986; 36(11):1490-1496.

81. Fowler JS, Volkow ND, Wang GJ, et al. Inhibition of monoamine oxidase B in the brains of smokers. Nature 1996; 379(6567):733-736.

82. Maggio R, Riva M, Vaglini F, et al. Nicotine prevents experimental parkinsonism in rodents and induces striatal increase of neurotrophic factors. J Neurochem 1998; 71(6):2439-2446.

83. Ross GW, Abbott RD, Petrovitch H, et al. Association of coffee and caffeine intake with the risk of Parkinson disease. JAMA 2000; 283(20):2674-2679.

84. Chen JF, Xu K, Petzer JP, et al. Neuroprotection by caffeine and $\mathrm{A}(2 \mathrm{~A})$ adenosine receptor inactivation in a model of Parkinson's disease. J Neurosci 2001; 21(10):RC143.

85. Ross GW, Petrovitch H. Current evidence for neuroprotective effects of nicotine and caffeine against Parkinson's disease. Drugs Aging 2001; 18(11):797-806.

86. Tsui JK, Calne DB, Wang Y, Schulzer M, Marion SA.
Occupational risk factors in Parkinson's disease. Can J Public Health 1999; 90(5):334-337.

87. Casals J, Elizan TS, Yahr MD. Postencephalitic parkinsonism--a review. J Neural Transm 1998; 105(6-7):645-676.

88. Taubenberger JK, Reid AH, Krafft AE, Bijwaard KE, Fanning TG. Initial genetic characterization of the 1918 "Spanish" influenza virus. Science 1997; 275(5307):1793-1796.

89. Calne DB, Lees AJ. Late progression of post-encephalitic Parkinson's syndrome. Can J Neurol Sci 1988; 15(2):135-138.

90. Lin SK, Lu CS, Vingerhoets FJG, et al. Isolated involvement of substantia nigra in acute transient parkinsonism: MRI and PET observation. Parkinsonism and Related Disorders 1995; 1:67-73.

91. Takahashi M, Yamada T, Nakajima S, et al. The substantia nigra is a major target for neurovirulent influenza A virus. J Exp Med 1995; 181(6):2161-2169.

92. Nielsen NM, Rostgaard K, Hjalgrim H, Aaby P, Askgaard D. Poliomyelitis and Parkinson disease. JAMA 2002; 287(13):1650-1651.

93. Jha N, Jurma O, Lalli G, et al. Glutathione depletion in PC12 results in selective inhibition of mitochondrial complex I activity. Implications for Parkinson's disease. J Biol Chem 2000; 275(34):26096-26101.

94. Merad-Boudia M, Nicole A, Santiard-Baron D, Saille C, CeballosPicot I. Mitochondrial impairment as an early event in the process of apoptosis induced by glutathione depletion in neuronal cells: relevance to Parkinson's disease. Biochem Pharmacol 1998; 56(5):645-655.

95. Han J, Cheng FC, Yang Z, Dryhurst G. Inhibitors of mitochondrial respiration, iron (II), and hydroxyl radical evoke release and extracellular hydrolysis of glutathione in rat striatum and substantia nigra: potential implications to Parkinson's disease. J Neurochem 1999; 73(4):1683-1695.

96. Soto-Otero R, Mendez-Alvarez E, Hermida-Ameijeiras A, Munoz-Patino AM, Labandeira-Garcia JL. Autoxidation and neurotoxicity of 6-hydroxydopamine in the presence of some antioxidants: potential implication in relation to the pathogenesis of Parkinson's disease. J Neurochem 2000; 74(4):1605-1612.

97. Olanow CW, Jenner P, Tatton NA, Tatton WG. Neurodegeneration and Parkinson's disease. In: Jankovic J, Tolosa E, (Eds). Parkinson's Disease and Movement Disorders. Baltimore, Maryland: Williams and Wilkins, 1998: 67-103.

98. Alam ZI, Jenner A, Daniel SE, et al. Oxidative DNA damage in the parkinsonian brain: an apparent selective increase in 8hydroxyguanine levels in substantia nigra. J Neurochem 1997; 69(3):1196-1203.

99. Sanchez-Ramos J, Overvik E, Overvik ABN. A marker of oxyradical-mediated DNA damage (8-hydroxy2 'deoxyguanosine) is increased in nigro-striatum of Parkinson's disease brain. Neurodegeneration 1994; 3:197-204.

100. Sian J, Dexter DT, Lees AJ, et al. Glutathione-related enzymes in brain in Parkinson's disease. Ann Neurol 1994; 36(3):356-361.

101. Calne DB. The free radical hypothesis in idiopathic parkinsonism: evidence against it. Ann Neurol 1992; 32(6):799-803.

102. Agid Y, Chase T, Marsden D. Adverse reactions to levodopa: drug toxicity or progression of disease? Lancet 1998; 351(9106):851852.

103. Murer MG, Dziewczapolski G, Menalled LB, et al. Chronic levodopa is not toxic for remaining dopamine neurons, but instead promotes their recovery, in rats with moderate nigrostriatal lesions. Ann Neurol 1998; 43(5):561-575.

104. Rajput AH. The protective role of levodopa in the human substantia nigra. Adv Neurol 2001; 86:327-336.

105. Effects of tocopherol and deprenyl on the progression of disability in early Parkinson's disease. The Parkinson Study Group. N Engl J Med 1993; 328(3):176-183.

106. Schulzer M, Mak E, Calne DB. The antiparkinson efficacy of deprenyl derives from transient improvement that is likely to be symptomatic. Ann Neurol 1992; 32(6):795-798.

107. Speiser Z, Levy R, Cohen S. Effects of N-propargyl-1(R)aminoindan (rasagiline) in models of motor and cognition disorders. J Neural Transm Suppl 1998; 52:287-300. 
108. Youdim MB, Gross A, Finberg JP. Rasagiline [N-propargyl$1 \mathrm{R}(+)$-aminoindan], a selective and potent inhibitor of mitochondrial monoamine oxidase B. Br J Pharmacol 2001; 132(2):500-506.

109. Tatton WG, Wadia JS, Ju WY, Chalmers-Redman RM, Tatton NA. (-)-Deprenyl reduces neuronal apoptosis and facilitates neuronal outgrowth by altering protein synthesis without inhibiting monoamine oxidase. J Neural Transm Suppl 1996; 48:45-59.

110. Waldmeier PC, Boulton AA, Cools AR, Kato AC, Tatton WG. Neurorescuing effects of the GAPDH ligand CGP 3466B. J Neural Transm Suppl 2000;60:197-214.

111. Naoi M, Maruyama W, Takahashi T, Akao Y, Nakagawa Y. Involvement of endogenous $\mathrm{N}$-methyl(R)salsolinol in Parkinson's disease: induction of apoptosis and protection by ()deprenyl. J Neural Transm Suppl 2000;58:111-121.

112. Leonard JV, Schapira AH. Mitochondrial respiratory chain disorders II: neurodegenerative disorders and nuclear gene defects. Lancet 2000; 355(9201):389-394.

113. Plasterer TN, Smith TF, Mohr SC. Survey of human mitochondrial diseases using new genomic/proteomic tools. Genome Biol 2001; 2(6):RESEARCH0021.

114. Golden TR, Melov S. Mitochondrial DNA mutations, oxidative stress, and aging. Mech Ageing Dev 2001; 122(14):1577-1589.

115. Melov S. Mitochondrial oxidative stress. Physiologic consequences and potential for a role in aging. Ann N Y Acad Sci 2000; 908:219-225.

116. Ebadi M, Muralikrishnan D, Pellett LJ, Murphy T, Drees K. Ubiquinone (coenzyme Q10) and complex I in mitochondrial oxidative disorder of Parkinson's disease. Proc West Pharmacol Soc 2000; 43:55-63.

117. Leret ML, San Millan JA, Fabre E, Gredilla R, Barja G. Deprenyl protects from MPTP-induced Parkinson-like syndrome and glutathione oxidation in rat striatum. Toxicology 2002; 170:165-171.

118. Gu M, Cooper JM, Taanman JW, Schapira AH. Mitochondrial DNA transmission of the mitochondrial defect in Parkinson's disease. Ann Neurol 1998; 44(2):177-186.

119. Janetzky B, Hauck S, Youdim MB, et al. Unaltered aconitase activity, but decreased complex I activity in substantia nigra pars compacta of patients with Parkinson's disease. Neurosci Lett 1994; 169(1-2):126-128.

120. Schapira AH, Cooper JM, Dexter D, et al. Mitochondrial complex I deficiency in Parkinson's disease. Lancet 1989; 1(8649):1269.

121. Cardellach F, Marti MJ, Fernandez-Sola J, et al. Mitochondrial respiratory chain activity in skeletal muscle from patients with Parkinson's disease. Neurology 1993; 43(11):2258-2262.

122. Yoshino $H$, Nakagawa-Hattori $Y$, Kondo $T$, Mizuno $Y$. Mitochondrial complex I and II activities of lymphocytes and platelets in Parkinson's disease. J Neural Transm Park Dis Dement Sect 1992; 4(1):27-34.

123. Mizuno Y, Matuda S, Yoshino H, et al. An immunohistochemical study on alpha-ketoglutarate dehydrogenase complex in Parkinson's disease. Ann Neurol 1994; 35(2):204-210.

124. Gu M, Gash MT, Cooper JM, et al. Mitochondrial respiratory chain function in multiple system atrophy. Mov Disord 1997; 12(3):418-422.

125. Agid Y. [Aging, disease and nerve cell death]. Bull Acad Natl Med 1995; 179(6):1193-1203.

126. Anglade P, Vyas S, Javoy-Agid F, et al. Apoptosis and autophagy in nigral neurons of patients with Parkinson's disease. Histol Histopathol 1997; 12(1):25-31.

127. Tatton NA, Maclean-Fraser A, Tatton WG, Perl DP, Olanow CW.
A fluorescent double-labeling method to detect and confirm apoptotic nuclei in Parkinson's disease. Ann Neurol 1998; 44(3 Suppl 1):S142-S148

128. Banati RB, Daniel SE, Blunt SB. Glial pathology but absence of apoptotic nigral neurons in long-standing Parkinson's disease. Mov Disord 1998; 13(2):221-227.

129. Jellinger KA. Cell death mechanisms in Parkinson's disease. J Neural Transm 2000; 107(1):1-29.

130. Kosel S, Egensperger R, von Eitzen U, Mehraein P, Graeber MB. On the question of apoptosis in the parkinsonian substantia nigra. Acta Neuropathol (Berl) 1997; 93(2):105-108.

131. Hartmann A, Hunot S, Michel PP, et al. Caspase-3: A vulnerability factor and final effector in apoptotic death of dopaminergic neurons in Parkinson's disease. Proc Natl Acad Sci USA2000; 97(6):2875-2880.

132. Jellinger KA, Stadelmann $\mathrm{CH}$. The enigma of cell death in neurodegenerative disorders. J Neural Transm Suppl 2000;60: 21-36.

133. Viswanath V, Wu Y, Boonplueang R, et al. Caspase-9 activation results in downstream caspase- 8 activation and bid cleavage in 1-methyl-4-phenyl-1,2,3,6-tetrahydropyridine-induced Parkinson's disease. J Neurosci 2001; 21(24):9519-9528.

134. Kahns S, Lykkebo S, Jakobsen LD, Nielsen MS, Jensen PH. Caspase-mediated parkin cleavage in apoptotic cell death. J Biol Chem 2002; 277(18):15303-15308.

135. Mogi M, Harada M, Kondo T, et al. bcl-2 protein is increased in the brain from parkinsonian patients. Neurosci Lett 1996; 215(2):137-139.

136. Mouatt-Prigent A, Karlsson JO, Agid Y, Hirsch EC. Increased Mcalpain expression in the mesencephalon of patients with Parkinson's disease but not in other neurodegenerative disorders involving the mesencephalon: a role in nerve cell death? Neuroscience 1996; 73(4):979-987.

137. Hunot S, Brugg B, Ricard D, et al. Nuclear translocation of NFkappaB is increased in dopaminergic neurons of patients with parkinson disease. Proc Natl Acad Sci USA1997; 94(14):75317536.

138. Beal MF. Energetics in the pathogenesis of neurodegenerative diseases. Trends Neurosci 2000; 23(7):298-304.

139. Uitti RJ, Rajput AH, Ahlskog JE, et al. Amantadine treatment is an independent predictor of improved survival in Parkinson's disease. Neurology 1996; 46(6):1551-1556.

140. McGeer PL, Itagaki S, Boyes BE, McGeer EG. Reactive microglia are positive for HLA-DR in the substantia nigra of Parkinson's and Alzheimer's disease brains. Neurology 1988; 38(8):12851291.

141. Langston JW, Forno LS, Tetrud J, et al. Evidence of active nerve cell degeneration in the substantia nigra of humans years after 1-methyl-4-phenyl-1,2,3,6-tetrahydropyridine exposure. Ann Neurol 1999; 46(4):598-605.

142. Cicchetti F, Brownell AL, Williams K, et al. Neuroinflammation of the nigrostriatal pathway during progressive 6-OHDA dopamine degeneration in rats monitored by immunohistochemistry and PETimaging. Eur J Neurosci 2002; 15(6):991-998

143. Defazio G, Dal Toso R, Benvegnu D, et al. Parkinsonian serum carries complement-dependent toxicity for rat mesencephalic dopaminergic neurons in culture. Brain Res 1994; 633(12):206-212

144. Aubin N, Curet O, Deffois A, Carter C. Aspirin and salicylate protect against MPTP-induced dopamine depletion in mice. $\mathrm{J}$ Neurochem 1998; 71(4):1635-1642. 